\title{
Parasitological, serological and molecular survey of camel trypanosomiasis in Somalia
}

\author{
Ahmed A. Hassan-Kadle ${ }^{1,2^{*}} \mathbb{0}$, Abdalla M. Ibrahim ${ }^{1 \dagger}{ }^{\prime}$ Hamisi S. Nyingilili ${ }^{3}$, Abdulkarim A. Yusuf ${ }^{1,2}$, \\ Thállitha S. W. J. Vieira ${ }^{2}$ and Rafael F. C. Vieira $2,4^{*}$
}

\begin{abstract}
Background: Camel trypanosomiasis or surra is of great concern in Somalia, since the country possesses the largest one-humped camel (Camelus dromedarius) population in the world. Civil war in Somalia has resulted in the destruction of educational, research, economic and social structures, making the country scores very low for most humanitarian indicators. Previous studies on detection of Trypanosoma species in Somali camels have only been performed during the 1990s using standard trypanosome detection methods (STDM). Considering the lack of state-of-the-art knowledge on camel trypanosomiasis in Somalia, the present study aimed to assess the prevalence of Trypanosoma spp. in three districts of Somalia.
\end{abstract}

Methods: A total of 182 blood samples from C. dromedarius from nomadic and dairy farms were evaluated using STDM, serological (CATT/T. evansi) and molecular (ITS1-PCR) methods.

Results: All samples were negative for Trypanosoma spp. by STDM. A total of 125/182 (68.7\%, 95\% Cl: 61.4-75.3\%) camels were seropositive for T. evansi by CATT/T. evansi. Camels reared in nomadic system were more likely to be seropositive for T. evansi than those under dairy production system (OR: 5.6, 95\% Cl: 2.1-15.2, P=0.0001). Five out of 182 (2.7\%, 95\% Cl: 0.9-6.3\%) camels tested positive for Trypanosoma sp. by ITS1-PCR. Sequencing of the ITS1 region of the Trypanosoma species detected herein revealed that camels were infected with T. evansi and T. simiae.

Conclusions: Trypanosoma evansi is highly prevalent in camels from the Banadir region of Somalia, particularly in nomadic herds. To our knowledge, this is the first study to confirm infections with T. evansi and T. simiae in Somali camels through DNA sequencing. Our data highlight the need for implementation of adequate control measures aiming to reduce the impact on camel production in the country.

Keywords: CATT/T. evansi, Dromedary, ITS1-PCR, Trypanosoma evansi, Trypanosoma simiae

\section{Background}

Trypanosomiasis are vector-borne diseases (VBD) that causes noticeable economic losses [1-3] and affects the development of both livestock and human health in

\footnotetext{
*Correspondence: akadle@abrar.edu.so; rvieira@ufpr.br

${ }^{\dagger}$ Ahmed A. Hassan-Kadle and Abdalla M. Ibrahim contributed equally to this work

${ }^{1}$ Abrar Research and Training Centre, Abrar University, Mogadishu, Somalia

${ }^{2}$ Department of Veterinary Medicine, Universidade Federal do Paraná, Curitiba, PR, Brazil

Full list of author information is available at the end of the article
}

Africa [4]. In Somalia, camel trypanosomiasis or surra is of great concern since the country possesses the largest one-humped camel (Camelus dromedarius) population in the world, estimated at nearly $8,000,000$ heads [5-7]. The economic importance of camels for Somalia is due to their role as a food source, as currency, as a means of transporting milk and water as well as an indicator of social issues [7]. Camels are uniquely adapted to survive and produce under extreme arid and semi-arid conditions of Somalia [7], with the majority of animals kept by nomadic pastoralists in the country $[6,7]$.

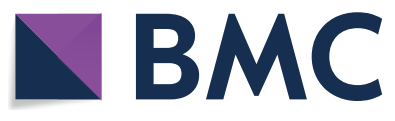

(c) The Author(s) 2019. This article is licensed under a Creative Commons Attribution 4.0 International License, which permits use, sharing, adaptation, distribution and reproduction in any medium or format, as long as you give appropriate credit to the original author(s) and the source, provide a link to the Creative Commons licence, and indicate if changes were made. The images or other third party material in this article are included in the article's Creative Commons licence, unless indicated otherwise in a credit line to the material. If material is not included in the article's Creative Commons licence and your intended use is not permitted by statutory regulation or exceeds the permitted use, you will need to obtain permission directly from the copyright holder. To view a copy of this licence, visit http://creativecommons.org/licenses/by/4.0/. The Creative Commons Public Domain Dedication waiver (http://creativecommons.org/publicdomain/zero/1.0/) applies to the data made available in this article, unless otherwise stated in a credit line to the data. 
Civil war in Somalia has resulted in the destruction of educational, research, economic and social structures, making the country score very low for most humanitarian indicators [8]. Currently, Somali communities and their livestock are experiencing a famine and suffering from preventable diseases, due to geographical and political isolation and lack of state-of-the-art knowledge. Recently, after some security and political settlement in the country, camels are kept around urban areas as a semi-intensive dairy farming system.

Worldwide, camels may be affected by tsetse-transmitted Trypanosoma species, including T. simiae, T. brucei, T. congolense and T. vivax $[9,10]$. In Somalia, previous studies on detection of Trypanosoma species were performed during the 1990s and reported T. evansi prevalence rates ranging from $1.7 \%$ to $56.4 \%$ in camels $[7,11]$. Additionally, T. simiae [9], T. congolense and T. brucei have also been detected in Somali camels by standard trypanosome detection methods (STDM) [11].

Clinical signs of trypanosomiasis may be absent in camels, and thus, laboratory diagnosis should be carried out for confirmation of infection. Several methods with varying degrees of sensitivity and specificity may be used for the diagnosis of trypanosomiasis. Standard trypanosome detection methods, such as microscopical examination of fresh or stained blood-smears, has been historically used in the identification of Trypanosoma spp. Unfortunately, this technique lacks sensitivity and specificity. A serological assay, the card agglutination test for T. evansi (CATT/T. evansi) is a rapid diagnostic test and currently recommended by the World Organization for Animal Health [2, 12]. Additionally, molecular analysis targeting the internal transcribed spacer 1 (ITS1) region provides multi-species-specific detection of trypanosomes in a single PCR [13], and has been used in epidemiological studies.

Although the National Tsetse and Trypanosomiasis Control Project (NTTCP) was established in the 1980s in Somalia, no control measures have been implemented to date. Accordingly, considering the lack of state-ofthe-art knowledge on camel trypanosomiasis in Somalia, the present study aimed to assess the prevalence of camel trypanosomiasis in three districts of Somalia using STDM, serological (CATT/T. evansi) and molecular (ITS1-PCR) methods.

\section{Methods}

\section{Study area}

Banadir region is one of the eighteen regions of the Federal Republic of Somalia. The region itself is coextensive with Mogadishu city, the capital of the country. It consists of 17 districts, and three of them were included in this study: Kahda ( $2^{\circ} 4^{\prime} 4.17^{\prime \prime}$ N, $45^{\circ} 14^{\prime} 16.16^{\prime \prime}$ E), Daynile $\left(2^{\circ} 4^{\prime} 24.61^{\prime \prime} \mathrm{N} 45^{\circ} 16^{\prime} 48^{\prime \prime} \mathrm{E}\right)$ and Yaqshid $\left(2^{\circ} 4^{\prime} 3.97^{\prime \prime} \mathrm{N}\right.$, $\left.45^{\circ} 21^{\prime} 35.9^{\prime \prime} \mathrm{E}\right)$. These districts are the main camel rearing areas in the investigated region.

\section{Study animals and blood sampling}

From December 2015 to March 2016, which represents the dry season in Somalia, a total of 182 C. dromedarius (176 females and 6 males) $\geq 2$ years-old from nomadic $(n=49)$ and dairy $(n=133)$ farms in the Kahda $(n=72)$, Daynile $(n=87)$ and Yaqshid $(n=23)$ districts were randomly evaluated. Blood samples were collected by jugular venipuncture. Three millilitres were placed into tubes without anticoagulant and kept at room temperature $\left(25{ }^{\circ} \mathrm{C}\right)$ until visible clot retraction; the samples were then centrifuged at $1500 \times g$ for $5 \mathrm{~min}$, serum separated and kept at $-20{ }^{\circ} \mathrm{C}$ for serological studies. One $\mathrm{ml}$ was placed into EDTA tubes for packed cell volume (PCV) measurement, microscopical detection of trypanosomes and preparation of blood spots on filter paper (Whatman no.4, Whatman, Springfield Mill, United Kingdom) for PCR analysis. A PCV of $0.26 \mathrm{l} / \mathrm{l}$ or less was used as an indicator of anaemia [14].

\section{Parasitological diagnosis of Trypanosoma spp.}

All camel blood samples were evaluated for the presence of Trypanosoma spp. by STDM. Briefly, a drop of fresh whole blood (after gentle mixing) was placed on a clean microscope slide, covered with coverslip and examined for the motile parasites, as previously described [15]. Giemsa-stained thin blood and buffy coat smears were also examined for the presence of Trypanosoma spp., as described elsewhere [2].

\section{Detection of $T$. evansi antibodies by card agglutination test (CATT/T. evansi)}

Camel serum samples were tested for the presence of T. evansi antibodies using the card agglutination test (CATT/T. evansi) [16], according to the manufacturer's instructions (Institute of Tropical Medicine, Antwerp, Belgium).

\section{DNA extraction and PCR for Trypanosoma spp.}

Genomic DNA was extracted from all 182 dried blood spots by Chelex-100 (Sigma-Aldrich, St. Louis, USA), as previously described [17]. The DNA samples were evaluated by a PCR assay targeting the ITS1 region of Trypanosoma species using previously described primers [18]. The PCR amplifications were performed in a total reaction volume of $25 \mu \mathrm{l}$ containing $0.5 \mu \mathrm{l}$ of $10 \mathrm{pM}$ of each primer, $12.5 \mu \mathrm{l}$ of $2 \times$ master mix (New England BioLabs, Ipswich, MA, USA), $9.5 \mu \mathrm{l}$ of PCR water and $2 \mu \mathrm{l}$ of each DNA template. PCR amplifications were performed with a thermal cycler $\left(\right.$ GeneAmp ${ }^{\circledR}$ PCR System 9700, Applied 
Biosystems $^{\circledR}$, Foster City, CA, USA). The amplification conditions used included an initial denaturation at $94{ }^{\circ} \mathrm{C}$ for $30 \mathrm{~s}$, followed by 30 cycles of $94{ }^{\circ} \mathrm{C}$ for $30 \mathrm{~s}, 58^{\circ} \mathrm{C}$ for $40 \mathrm{~s}, 68^{\circ} \mathrm{C}$ for $1 \mathrm{~min}$, with a final extension step at $68^{\circ} \mathrm{C}$ for $5 \mathrm{~min}$ and cooling at $4{ }^{\circ} \mathrm{C}$. Nuclease-free water and a T. evansi-positive sample were used as negative and positive control, respectively, in all PCR runs. The amplified PCR products were analysed by electrophoresis in a $1.5 \%$ agarose gel at $100-120 \mathrm{~V}$ for $60 \mathrm{~min}$. Quick Loading 100 bp DNA ladder (New England BioLabs) was included on each gel, stained with ethidium bromide, and finally visualized under ultraviolet (UV) illuminator $\left(\right.$ UVITEC $^{\text {TM }}$, Cambridge, UK).

\section{Sequencing and phylogenetic analysis}

Amplicons ( $400 \mathrm{bp}$ ) obtained from two Trypanosomapositive samples were sequenced in both directions by the Sanger method and were assembled using Geneious Prime ${ }^{\circledR}$ 2019.1. Consensus sequences were subjected to BLASTn analysis [19] for determining the identity with the sequences deposited in the GenBank database.

The Trypanosoma ITS1 region sequences (GenBank: MH885470, MH885471) were aligned with sequences from GenBank using ClustalW [20] and alignments were improved using GUIDANCE2 [21]. The best-fit model of nucleotide substitution was determined using jModeltest v.2.1.10 [22] and was set as F81+G in the maximum likelihood (ML) phylogenetic estimation on the CIPRES Science Gateway [23], including 1000 bootstrap replicates. The resulting tree was visualized using FigTree software version 1.4.3 [24] and the final layout was rendered using Inkscape version 0.92 .3 [25].

\section{Data management and analysis}

The PCV data were not normally distributed (Shapiro-Wilk normality test, $W=0.98, P=0.018)$. Therefore, a non-parametric Mann-Whitney test was used to compare the $\mathrm{PCV}$ concentration between
Trypanosoma-infected and non-infected camels. Either Chi-square or Fisher's exact test was used to assess association of the individual variables (district and production system) with Trypanosoma spp. infection. Odds ratio (OR), 95\% confidence intervals (95\% CI) and $P$-values were calculated, and results were considered significant when $P<0.05$. Data were compiled and analysed by Statistical Package for Social Sciences (SPSS) version 25 (IBM Corp., Armonk, NY, USA).

\section{Results}

All samples were negative for Trypanosoma spp. by STDM. A total of $125 / 182$ (68.7\%, 95\% CI: 61.4-75.3\%) camels were seropositive for T. evansi by CATT/T. evansi. Camels reared in the nomadic system were more likely to be seropositive to $T$. evansi than those reared under the dairy production system (OR: 5.6, 95\% CI: 2.1-15.2, $P=0.0001$ ). No associations between seropositivity for $T$. evansi and the three districts of Somalia evaluated were found $(P>0.05)$. The prevalence of Trypanosoma sp. for each variable evaluated is summarized in Table 1.

Five out of 182 (2.7\%, 95\% CI: 0.9-6.3\%) camels tested positive for Trypanosoma spp. by ITS1-PCR. Concordant results for Trypanosoma spp. presence determined by CATT/T. evansi and ITS1-PCR were found in three of 182 camels (1.6\%, 95\% CI: $0.3-4.7 \%)$.

The mean PCV concentration for camels was $0.27 \mathrm{l} / \mathrm{l}$. A total of 61/182 (33.5\%, 95\% CI: 26.7-40.9\%) camels were anaemic. No statistical difference $(U=2944, Z=-1.89$, $P=0.059)$ was found in mean PCV between Trypanosoma-seropositive $(0.27 \mathrm{l} / \mathrm{l})$ and Trypanosoma-seronegative camels $(0.28 \mathrm{l} / \mathrm{l})$. Association between Trypanosoma infection and anaemia was not found $\left(\chi^{2}=1.93, d f=1\right.$, $P=0.165)$.

Five Trypanosoma-positive samples were sequenced; however, only two sequences yielded consistent data. One Trypanosoma-positive sample (GenBank: MH885471) sequenced showed 99.78\% (460/461 bp)

Table 1 Prevalence of camel trypanosomiasis within each variable studied

\begin{tabular}{|c|c|c|c|c|c|c|c|c|}
\hline \multirow[t]{2}{*}{ Variable } & \multicolumn{4}{|c|}{ CATT/T. evansi } & \multicolumn{4}{|c|}{ ITS1-PCR } \\
\hline & $+/ n$ & Prevalence (\%) (95\% Cl) & $P$-value & $\mathrm{OR}(95 \% \mathrm{Cl})$ & $+/ n$ & Prevalence (\%) (95\% Cl) & $P$-value & $\mathrm{OR}(95 \% \mathrm{Cl})$ \\
\hline \multicolumn{9}{|c|}{ Production system } \\
\hline Nomadic & $44 / 49$ & $89.8(77.8-96.6)$ & $0.0001\left(x^{2}=13.9\right)$ & $5.6(2.1-15.2)$ & $2 / 49$ & $4.1(0.5-14)$ & $0.408\left(x^{2}=0.45\right)$ & $1.8(0.3-11.4)$ \\
\hline Dairy & $81 / 133$ & $60.9(52.1-69.2)$ & & & $3 / 133$ & $2.3(0.5-6.5)$ & & \\
\hline \multicolumn{9}{|l|}{ District } \\
\hline Daynile & $62 / 87$ & $71.3(60.6-80.5)$ & $0.242\left(x^{2}=1.38\right)$ & $1.5(0.8-2.9)$ & $2 / 87$ & $2.3(0.3-8.1)$ & $0.502\left(x^{2}=0.45\right)$ & $0.5(0.09-3.33)$ \\
\hline Yaqshid & $18 / 23$ & $78.3(56.3-92.5)$ & $0.164\left(x^{2}=1.94\right)$ & $2.2(0.7-6.5)$ & $0 / 23$ & $0.0(0.0-14.8)$ & $0.989\left(x^{2}=0.32\right)$ & 0.0 \\
\hline Kahda & $45 / 72$ & $62.5(50.3-73.6)$ & & & $3 / 72$ & $4.2(0.9-8.8)$ & & \\
\hline
\end{tabular}


identity to T. evansi ITS1 region sequences detected in camels from Iran (GenBank: KX898422, KX898423). The other sequence obtained (GenBank: MH885470) showed 99.25\% (398/401 bp) and 98\% (393/401 bp) identity with T. simiae ITS1 region sequence from warthogs (Phacochoerus africanus) of Tanzania and Zambia, respectively (GenBank: JN673387 and JN673386). The phylogenetic tree based on sequences of the ITS1 region indicated that T. evansi obtained herein was closely related to T. evansi detected in camels from Iran, whereas T. simiae detected in the present study was closely related to $T$. simiae detected in warthog from Zambia (Fig. 1).

\section{Discussion}

To the author's knowledge, this is the first study to combine STDM, serological and molecular detection of Trypanosoma and assess these results for potential associations with epidemiological data collected from camels in Somalia. Herein, overall $69.8 \%$ camels from the Banadir region of Somalia were positive for Trypanosoma spp. Interestingly, Trypanosoma prevalence found herein was higher than previous studies performed in camels from Somalia which have shown prevalence rates ranging from $1.7 \%$ to $56.4 \%$ by STDM $[7,11]$ and complement fixation test [7]. Differences among the prevalence of Trypanosoma may be explained by the camel population and management, diagnostic test used, and tsetse seasonal dynamics (rainy $v s$ dry season).

Sequencing of the ITS1 region of the Trypanosoma species detected herein revealed that camels were infected with T. evansi and T. simiae (Fig. 1). Although previous studies in Somalia have reported T. evansi, T. simiae, T. brucei and T. congolense infecting camels by STDM, the present study is the first to confirm infections with Trypanosoma spp. in camels in this country by DNA sequencing.

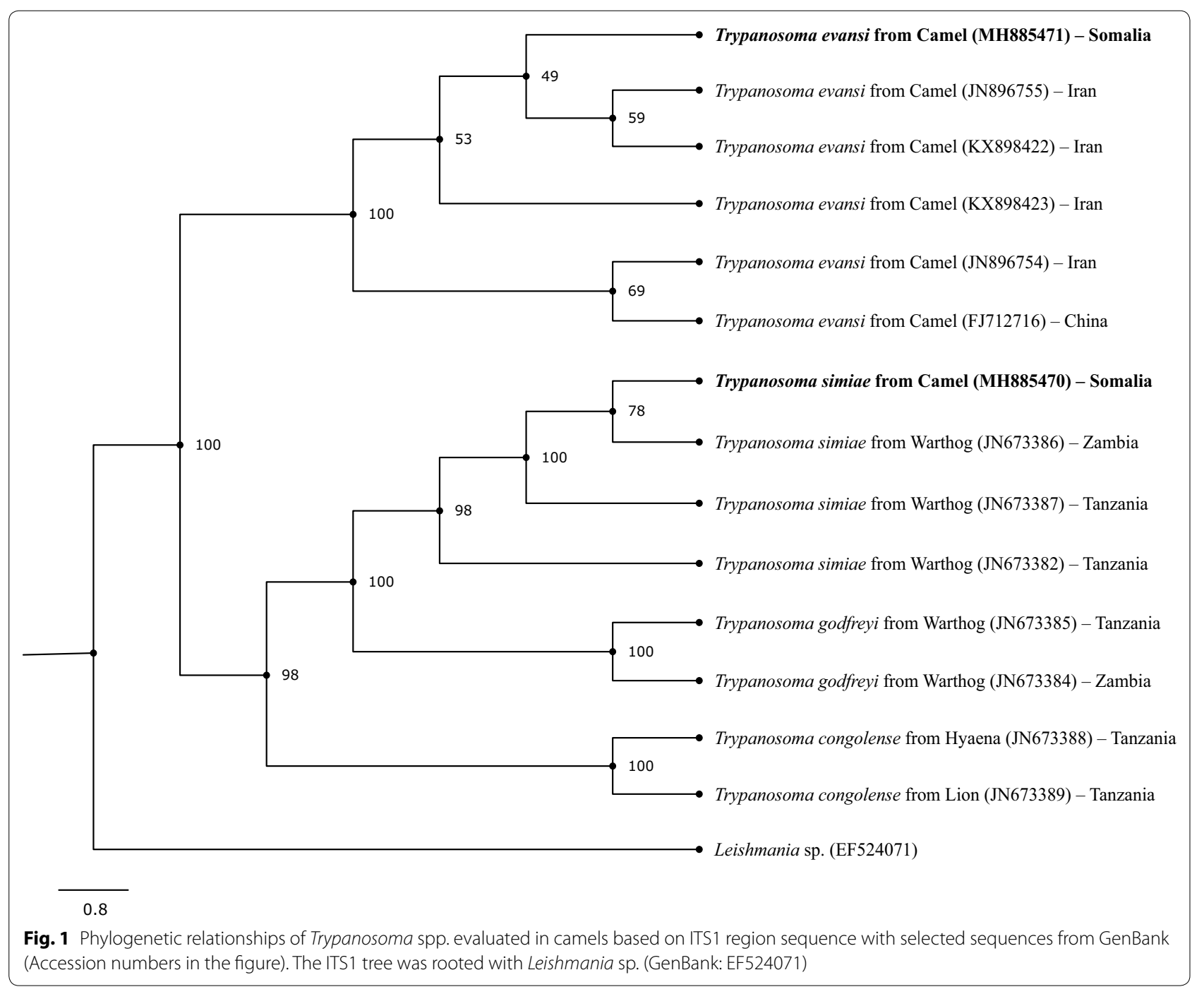


In the present study, all animals were negative for Trypanosoma by STDM, while the molecular and serological prevalence were $2.7 \%$ and $68.7 \%$, respectively. Combining CATT/T. evansi and ITS1-PCR has increased the prevalence of Trypanosoma to $69.8 \%$, corroborating with previous studies suggesting that improved sensitivity and specificity for detection of VBD pathogens can be achieved using different diagnostic methods [26]. The difference between the ratio of ITS1-PCR and parasitological method found herein may be explained by low parasitaemia which is typical for the chronic phase of infection [27]; this is also supported by the high seroprevalence observed indicating that a large proportion of camels are exposed to the parasite.

Herein, the T. evansi seroprevalence rate was significantly higher in nomadic camels as compared to dairy farm camels $(P=0.0001)$. Previous studies on Somali camels have shown that animals living in riverine zones of the country were more likely to acquire infection by Trypanosoma species than those living in inland zones [7]. The camels' role in the subsistence sector is not primarily for supply of meat and money, but mainly for provision of milk [7]. Considering that nomadic herders usually depend on traditional ethno-veterinary remedies to treat and prevent diseases in their camels $[28,29]$, the high T. evansi seroprevalence found herein highlights the need for implementation of adequate control measures aiming to reduce the impact of trypanosomes on camel production in Somalia. On the other hand, dairy animals evaluated in the present study were frequently examined by veterinary practitioners and treated with Suramin (data not shown), which may explain the low seroprevalence found.

\section{Conclusions}

Trypanosoma evansi is highly prevalent in camels from the Banadir region of Somalia, particularly in nomadic herds. To our knowledge, this is the first study to confirm infections with T. evansi and T. simiae in Somali camels by DNA sequencing. Our data highlight the need for implementation of adequate control measures aiming to reduce the impact of trypanosomes on camel production in the country, which possesses the largest one humped camel population in the world.

\footnotetext{
Abbreviations

ARTC: Abrar Research and Training Centre; AU: Abrar University; BLAST: basic local alignment search tool; CATT: card agglutination test for trypanosomiasis; Cl: confidence interval; DNA: deoxyribonucleic acid; GOHi: Global One Health Initiative; ITS: internal transcribed spacer; ML: maximum likelihood; NTTCP: National Tsetse and Trypanosomiasis Control Project; OR: odds ratio; PCR: polymerase chain reaction; PCV: packed cell volume; SPSS: statistical package for social sciences; STDM: standard trypanosome detection methods; UV: ultraviolet; VBD: vector-borne diseases; VVBDI: Vector and Vector Borne Diseases Institute.
}

\section{Acknowledgements}

The authors thank Dr. Ehab Mossaad, Sudan University of Science and Technology, Sudan for providing CATT/T. evansi kits. We also thank the team at VVBDI, Tanzania for their molecular services. The Brazilian National Council of Scientific and Technological Development (CNPq) provided a fellowship of research productivity (PQ) to Dr. Rafael Vieira.

\section{Authors' contributions}

AAHK, AMI and RFCV designed the study. AAHK, AMI and AAY collected the data. AAHK and AMI curated the data. AAHK, AMI, AAY, HSN, TSWJV and RFCV carried out the methodology. AAHK, AMI, AAY and TSWJV performed the data analysis. AAHK, AMI, HSN and RFCV drafted the manuscript. All authors read and approved the final manuscript.

\section{Funding}

This study was financially supported by the Abrar University, Somalia, with Reference number AURG02012015. The sponsor had no role in the design of the study, collection, analysis and interpretation of data, writing the manuscript and the decision to submit the article for publication.

\section{Availability of data and materials}

Data supporting the conclusions of this article are provided within the article. Sequences were submitted to the GenBank database under the Accession numbers MH885470 and MH885471 for Trypanosoma ITS1 region of T. simiae and T. evansi, respectively.

\section{Ethics approval and consent to participate}

This study was approved by the ethical committee of Abrar University, Somalia (Reference number AU/ARTC/EC/02/2015). All camel owners gave consent to sample their animals.

\section{Consent for publication}

Not applicable.

\section{Competing interests}

The authors declare that they have no competing interests.

\section{Author details}

${ }_{1}^{1}$ Abrar Research and Training Centre, Abrar University, Mogadishu, Somalia. ${ }^{2}$ Department of Veterinary Medicine, Universidade Federal do Paraná, Curitiba, PR, Brazil. ${ }^{3}$ Vector and Vector Borne Diseases Institute, Tanga, Tanzania. ${ }^{4}$ Global One Health Initiative (GOHi), The Ohio State University, Columbus, $\mathrm{OH}, \mathrm{USA}$.

Received: 30 July 2019 Accepted: 14 December 2019

Published online: 21 December 2019

\section{References}

1. Onditi SJ, Silayo RS, Kimera SI, Kimbita EN, Mbilu TJNK. Preliminary studies on prevalence and importance of goat trypanosomosis in selected farms in Morogoro districts, Tanzania. LRRD. 2007;19:20-35.

2. OIE-World organisation for animal health. Trypanosoma evansi infection (surra). Chapter 3.1.21. In: Manual of diagnostic tests and vaccines for terrestrial animals 2012. 7th ed. Paris: OIE; 2012. http://www.oie.int/filea dmin/Home/eng/Health_standards/tahm/3.01.21_TRYPANO_SURRA.pdf. Accessed 8 Mar 2019.

3. Angara TEE, Ismail AA, Ibrahim AM. An overview on the economic impacts of animal trypanosomiasis. Glob J Res Anal. 2014;3:275-84.

4. Losos GJ. Infectious tropical diseases of domestic animals. Essex: Longman Scientific \& Technical; 1986.

5. Wilson RT, Araya A, Melaku A. The one-humped camel. An analytical and annotated bibliography 1980-1989. The United Nations Sudano-Sahelian Office (UNSO). 1990;3:1-301.

6. Abdurahman O, Bornstein S. Diseases of camels in Somalia and prospect for better health. Nomadic Peoples. 1991;29:104-12.

7. Baumann MPO, Zessin KH. Reproductivity and health of camels (Camelus dromedarius) in Somalia: association with trypanosomiasis and brucellosis. Trop Anim Health Prod. 1992;24:145-56. 
8. CIA-Central Intelligence Agency. The World Factbook: Somalia. 2019. https://www.cia.gov/library/publications/the-world-factbook/geos/print _so.html. Accessed 29 May 2019

9. Pellegrini D. Trypanosoma simiae (Bruce) infection of the camel. East Afr Agric J. 1948;13:207-9.

10. Enwezor FNC, Sackey AKB. Camel trypanosomosis-a review. Vet Arhiv. 2005;75:439-52.

11. Dirie MF, Walbanks KR, Aden AA, Bornstein S, Ibrahim MD. Camel trypanosomosis and its vectors in Somalia. Vet Parasitol. 1989:32:285-9.

12. Bajyana SE, Hamers R. A card agglutination test (CATT) for veterinary use based on an early VAT RoTat 1/2 of Trypanosoma evansi. Ann Soc Belg Med Trop. 1988;68:233-40.

13. Salim B, Bakheit AM, Kamau K, Nakamura I, Sugimoto C. Molecular epidemiology of camel trypanosomiasis based on ITS1 rDNA and RoTat 1.2 VSG gene in the Sudan. Parasit Vectors. 2011;4:31

14. Marcotty T, Simukoko H, Berkvens D, Vercruysse J, Praet N, Van den Bossche P. Evaluating the use of packed cell volume as an indicator of trypanosomal infections in cattle in Eastern Zambia. Prev Vet Med. 2008;87:288-300.

15. Schalm OW. Veterinary hematology. 2nd ed. Philadelphia: Lea \& Febiger; 1971.

16. Ibrahim AM, Ismail AA, Majid AA, Sidig HS, Osman ME, Rahman AH. Prevalence of camel trypanosmiasis and its effect on PCV as health indicator in the Sudan. Univ Khartoum J Vet Med Anim Prod. 2011;2:138-50.

17. Ahmed AH, MacLeod ET, Hide G, Welburn SC, Picozzi K. The best practice for preparation of samples from FTA ${ }^{\circledR}$ cards for diagnosis of blood borne infections using African trypanosomes as a model system. Parasit Vectors. 2011:4:68.

18. Njiru ZK, Constantine CC, Guya S, Crowther J, Kiragu JM, Thompson RC, Dávila AM. The use of ITS1 rDNA PCR in detecting pathogenic African trypanosomes. Parasitol Res. 2005;95:186-92.

19. Altschul SF, Gish W, Miller W, Myers EW, Lipman DJ. Basic local alignment search tool. J Mol Biol. 1990;215:403-10.

20. Thompson JD, Higgins DG, Gibson TJ. CLUSTAL W: improving the sensitivity of progressive multiple sequence alignment through sequence weighting, position-specific gap penalties and weight matrix choice. Nucleic Acids Res. 1994;22:4673-80.

21. Sela I, Ashkenazy H, Katoh K, Pupko T. GUIDANCE2: accurate detection of unreliable alignment regions accounting for the uncertainty of multiple parameters. Nucleic Acids Res. 2015;43:W7-14.

22. Darriba D, Taboada GL, Doallo R, Posada D. jModelTest 2: more models, new heuristics and parallel computing. Nat Methods. 2012;9:772.

23. Miller MA, Pfeiffer W, Schwartz T. Creating the CIPRES science gateway for inference of large phylogenetic trees. In: Proceedings of the gateway computing environments workshop (GCE), 14 Nov 2010, New Orleans, LA; p. 1-8.

24. Rambaut A. FigTree v1.4.3. 2016. http://tree.bio.ed.ac.uk/software/figtree/ Accessed 24 May 2019

25. Albert M, Andler JA, Bah T, Barbry-Blot P, Barraud JF, Barton C, Yip D. Inkscape v0.92.3. 2018. http://www.inkscape.org/. Accessed 24 May 2019.

26. Maggi RG, Birkenheuer AJ, Hegarty BC, Bradley JM, Levy MG, Breitschwerdt EB. Comparison of serological and molecular panels for diagnosis of vector-borne diseases in dogs. Parasit Vectors. 2014;7:127.

27. Shahzad W, Munir R, Khan MS, Ahmad MD, ljaz M, Ahmad A, lqbal M. Prevalence and molecular diagnosis of Trypanosoma evansi in Nili-Ravi buffalo (Bubalus bubalis) in different districts of Punjab (Pakistan). Trop Anim Health Prod. 2010:42:1597-9.

28. Catley A, Walker R. Somali ethnoveterinary medicine and private animal health services: can old and new systems work together? In: Ethnoveterinary medicine: alternatives for livestock development. Proceedings of the international conference on ethnoveterinary medicine, research and development. Pune, India, 4th-6th November, 1997.

29. Aziz MA, Khan AH, Adnan M, Ullah H. Traditional uses of medicinal plants used by Indigenous communities for veterinary practices at Bajaur Agency, Pakistan. J Ethnobiol Ethnomed. 2018;14:11.

\section{Publisher's Note}

Springer Nature remains neutral with regard to jurisdictional claims in published maps and institutional affiliations.
Ready to submit your research? Choose BMC and benefit from:

- fast, convenient online submission

- thorough peer review by experienced researchers in your field

- rapid publication on acceptance

- support for research data, including large and complex data types

- gold Open Access which fosters wider collaboration and increased citations

- maximum visibility for your research: over $100 \mathrm{M}$ website views per year

At BMC, research is always in progress.

Learn more biomedcentral.com/submissions 